\title{
Influence of cold atmospheric plasma on dental implant materials - an in vitro analysis
}

\author{
Gunar Wagner $^{1}\left({ }^{10} \cdot\right.$ Benedikt Eggers $^{2} \cdot$ Dirk Duddeck $^{3,4} \cdot$ Franz-Josef Kramer $^{2,5} \cdot$ Christoph Bourauel $^{6} \cdot$ Søren Jepsen $^{1}$. \\ James Deschner ${ }^{7} \cdot$ Marjan Nokhbehsaim $^{8}$
}

Received: 15 June 2021 / Accepted: 1 November 2021 / Published online: 15 December 2021

(c) The Author(s) 2021

\begin{abstract}
Background and objectives Alterations in the microenvironment of implant surfaces could influence the cellular crosstalk and adhesion patterns of dental implant materials. Cold plasma has been described to have an influence on cells, tissues, and biomaterials. Hence, the mechanisms of osseointegration may be altered by non-thermal plasma treatment depending on different chemical compositions and surface coatings of the biomaterial. The aim of the present study is to investigate the influence of cold atmospheric plasma (CAP) treatment on implant surfaces and its biological and physicochemical side effects. Materials and methods Dental implant discs from titanium and zirconia with different surface modifications were treated with CAP at various durations. Cell behavior and adhesion patterns of human gingival fibroblast (HGF-1) and osteoblastlike cells (MG-63) were examined using scanning electron microscopy and fluorescence microscopy. Surface chemical characterization was analyzed using energy-dispersive X-ray spectroscopy (EDS). Quantitative analysis of cell adhesion, proliferation, and extracellular matrix formation was conducted including real-time PCR.

Results CAP did not affect the elemental composition of different dental implant materials. Additionally, markers for cell proliferation, extracellular matrix formation, and cell adhesion were differently regulated depending on the application time of CAP treatment in MG-63 cells and gingival fibroblasts.

Conclusions CAP application is beneficial for dental implant materials to allow for faster proliferation and adhesion of cells from the surrounding tissue on both titanium and zirconia implant surfaces with different surface properties.

Clinical relevance The healing capacity provided through CAP treatment could enhance osseointegration of dental implants and has the potential to serve as an effective treatment option in periimplantitis therapy.
\end{abstract}

Keywords Cold atmospheric plasma $\cdot$ Dental implants $\cdot$ Bone remodeling $\cdot$ Periimplantitis

Gunar Wagner

drgunarwagner@gmail.com

1 Department of Periodontology, Operative and Preventive Dentistry, Center of Dento-Maxilo-Facial Medicine, University of Bonn, Welschnonnenstr. 17, 53111 Bonn, Germany

2 Department of Oral Surgery, Center of Dento-Maxillo-Facial Medicine, University of Bonn, 53111 Bonn, Germany

3 Department of Prosthodontics, Geriatric Dentistry and Craniomandibular Disorders, University Charité Berlin, 14197 Berlin, Germany

4 Research Department, CleanImplant Foundation, 10117 Berlin, Germany
5 Department of Cranio-Maxillofacial Surgery, Center of Dento-Maxillo-Facial Medicine, University of Bonn, 53111 Bonn, Germany

6 Department of Oral Technology, School of Dentistry, University of Bonn, 53111 Bonn, Germany

7 Department of Periodontology and Operative Dentistry, University of Mainz, 55131 Mainz, Germany

8 Section of Experimental Dento-Maxillo-Facial Medicine, Center of Dento-Maxillo-Facial Medicine, University of Bonn, 53111 Bonn, Germany 


\section{Introduction}

The main goal in modern dental implantology is to maintain biological stable conditions and prevent peri-implant diseases despite a high microbial load in the oral cavity and increased mechanical stress. The process of osseointegration is determined by a cascade of cellular and molecular mechanisms involving the recruitment of different cell types and levels of morphological differentiation as well as inflammatory conditions in conjunction with matrix proteins and growth factors [1]. Improvements for a precise interaction between the biomaterial and the cells of the target tissue could be achieved by considering the influence of the biomaterial's surface properties on the cell-matrix crosstalk. Histological and biomechanical evidence strongly suggests that different surface alterations could manipulate soft and hard tissue integration and therefore may influence healing and anchorage of the dental implant $[2,3]$. In this context, different surface structures and nanotechnologies for coating of dental implants have been developed and today, there is a broad range of them used in combination with various implant designs and materials on the market [4-6]. Systematic reviews highlight the different coatings on titanium surfaces to achieve better osseointegration and faster loading in clinical conditions [7, 8], such as calcium phosphate [9] or titanium dioxide or nanoparticles $[10,11]$. In addition, in vitro studies indicate that zirconium dioxide $\left(\mathrm{ZrO}_{2}\right)$ implants may promote osseointegration [12]. Nevertheless, peri-implant diseases are a growing challenge, but the pathogenesis is dissimilar to periodontitis showing distinct patterns of biofilm formation with diversity in corrosion/tribocorrosion for implant materials. Deregulation of inflammation triggered by changes of the microbiome and immune modulation of the individual can lead to severe tissue destruction $[13,14]$.

Decontamination techniques should promote optimal bacterial reduction without changing the topographical characteristics of dental implants favoring cellular recolonization and consequent re-osseointegration. Regarding the treatment of peri-implant diseases, it should be considered that different surface properties of zirconia and titanium must be considered. Despite the removal of bacterial pathogens, the elimination of organic nitrogen compounds represents a key factor in those efforts to restore and heal previously infected areas [15]. It could be revealed that biological reintegration of dental implants consistently occurred at sites where exposed surfaces were replaced with a pristine component [16]. Various innovative strategies using laser, photodynamic therapy, and ozone $\left(\mathrm{O}_{3}\right)$ as well as cold atmospheric plasma (CAP) treatment have emerged to provide a stable debridement procedure that seeks to meet all necessary criteria for periodontal healing [17-20]. Cold atmospheric plasma is a highly reactive gas that has been described to generate a variety of reactive species (ozone, reactive oxygen, and nitrogen species) with antimicrobial effects [21]. Although the precise mode of action is still under investigation, similar efficacy to the effect of $0.2 \%$ chlorhexidine digluconat could be observed in bacterial biofilms [22]. Argon-based atmospheric plasma affects the initial adhesion of bone marrow cells and stimulates bioactivity on titanium implant surfaces [23]. CAP operates at room temperature utilizing portable equipment and represents a promising technology to achieve early osseointegration of biocompatible implant surfaces. Hence, it is a promising and affordable option to use during surgery immediately prior to implant placement or during periimplantitis treatment. In previous studies, we have demonstrated a stimulating effect of ambient air CAP on human periodontal cells, keratinocytes, fibroblasts, cementoblasts, and osteoblast-like cells [24-26]. Since it remains unclear to what extent the application of ambient CAP has an impact on cellular homeostasis on implant surfaces, we seek to determine the precise mechanism of CAP treatment on cells involved in osseointegration and soft tissue stabilization with possible material alterations on dental implants. The main aim was to provide a qualitative assessment for the treatment of titanium and zirconia materials using ambient CAP in vivo. Different surface modifications are examined to draw conclusions for clinical implications on the use of CAP either to promote osseointegration or as a possible tool for the treatment of peri-implant diseases (Fig. 1).

\section{Materials and methods}

\section{Implant material samples}

Commercially pure grade IV titanium discs with machined surface $(\varnothing 5.2 \mathrm{~mm}$, thickness $1.5 \mathrm{~mm} / \mathrm{Sa}$ : $0.76 \mu \mathrm{m}$; FairImplant $^{\mathrm{TM}}$, Bönningstedt, Germany) were analyzed. Samples coated with a calcium-phosphate layer (BONIT ${ }^{\circ}, \varnothing 10 \mathrm{~mm}$, thickness $2.0 \mathrm{~mm} / \mathrm{Sa}: 1.35 \mu \mathrm{m}$ ) were used as comparison. DOT GmbH, Rostock, Germany, manufactured the coating layer. Zirconia discs comprising composite ceramic made of zirconium oxide and aluminum oxide (Ziraldent ${ }^{\circledR}$, $\emptyset 5.2 \mathrm{~mm}$, thickness $1.5 \mathrm{~mm} / \mathrm{Sa}: 0.49 \mu \mathrm{m}$ ) were used in another group. Additionally, coated samples with a microporous implant surface made from proven zirconium oxide with equivalent dimensions were analyzed (Zircapore ${ }^{\circledR}$, Sa: $0.43 \mu \mathrm{m})$. Metoxit AG, Switzerland, kindly provided zirconia specimens. Surface roughness was determined by the authors of this study using EDS (Fig. 2). 
Fig. 1 The design of the study with the sample size for each experiment

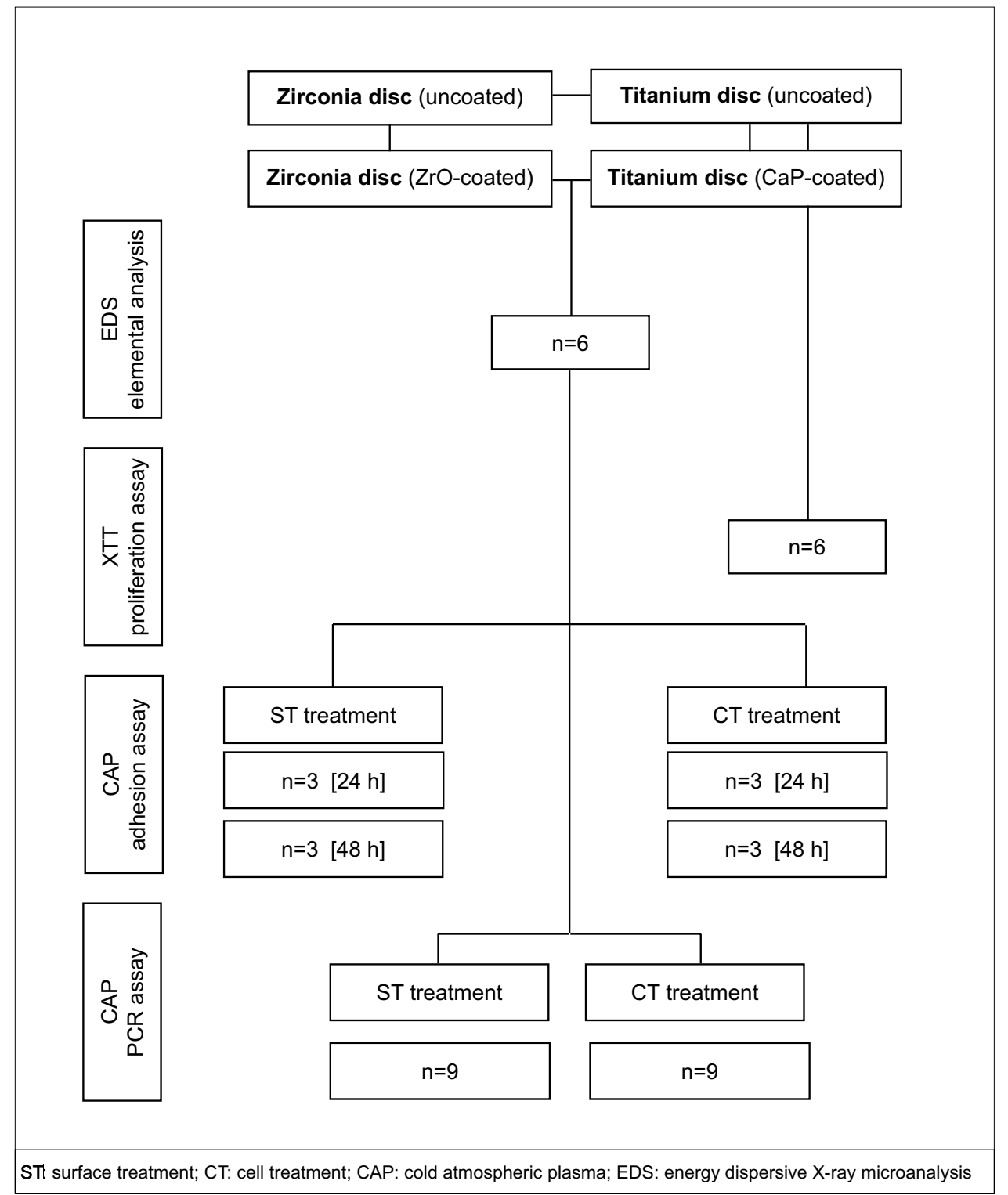

\section{CAP application}

Ambient air CAP was generated by a dielectric barrier discharge (Plasma ONE MEDICAL, Plasma MEDICAL SYSTEMS® GmbH, Nievern, Germany). Optimal time, intensity, and distance were selected after preliminary experiments (Kleineidam et al., 2019). The material surfaces of the specimens were exposed using CAP within a distance of $1 \mathrm{~cm}$ using the PS12 instrument probe at $18 \mathrm{kV}$. The time of application differed between 60 and $120 \mathrm{~s}$ of CAP treatment for different zirconia and titanium surfaces (Fig. 3).

\section{Cell culture and adherence experiment}

Human osteoblast-like cells (MG-63) (ATCC, CRL1427TM) (Sigma-Aldrich, Taufkirchen, Germany) or
Human Gingival Fibroblasts (HGF-1) (330703HPL; CLS Cell Lines Service GmbH, Eppelheim, Germany) were cultured in Dulbecco's modified essential medium (DMEM, Invitrogen, Germany) supplemented with $10 \%$ fetal bovine serum (FBS, Invitrogen), 100 unit's penicillin, and $100 \mu \mathrm{g} /$ $\mathrm{mL}$ streptomycin (Invitrogen) at $37{ }^{\circ} \mathrm{C}$ in a humidified atmosphere of $5 \% \mathrm{CO}_{2}$ and $95 \%$ humidity. For further studies, cells were seeded into $35 \times 10 \mathrm{~mm}$ Petri dishes and cultured to $70 \%$ confluence. Cell culture medium was replaced every 2 days. For each experiment, FBS concentration was reduced to $1 \% 1$ day prior to start. Different experimental groups were created to discriminate the effect of CAP between the cells and the surface properties. The first group received surface treatment $(\mathrm{ST})$ of the specimen prior to cell seeding. In the other group, CAP stimulation of the cell suspension took place prior to seeding on the untreated implant 

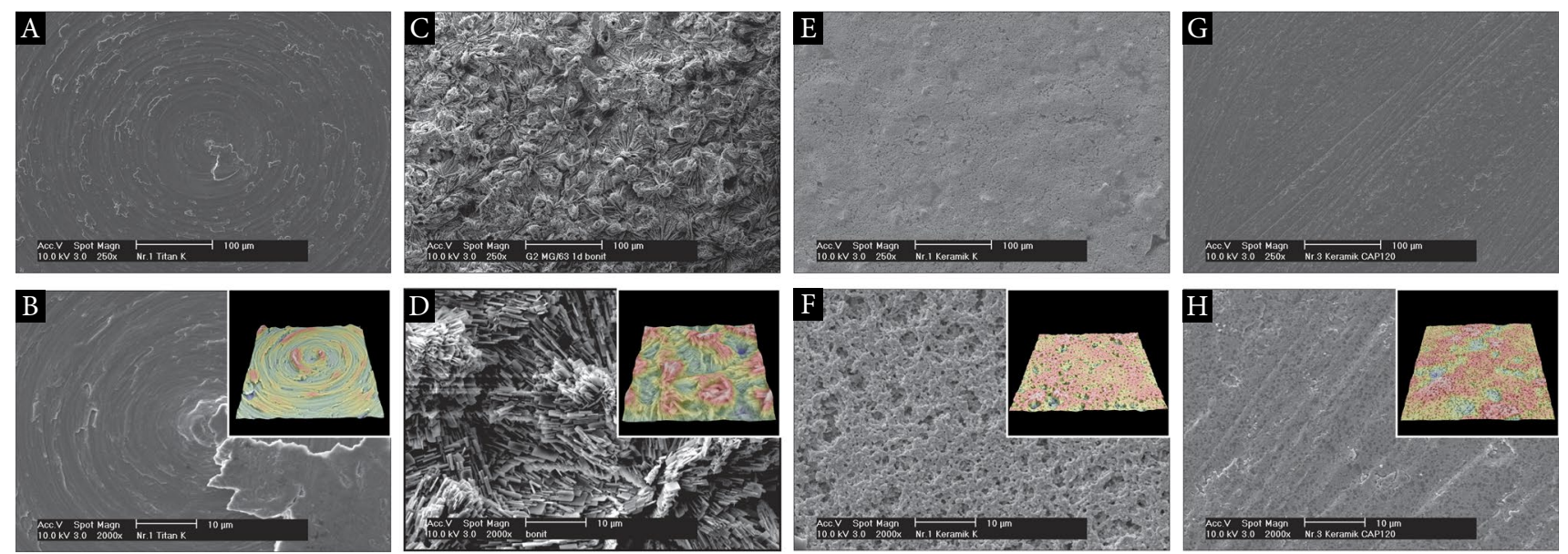

Fig. 2 Scanning electron micrographs and 3D roughness reconstruction/heightmap calculation images (inserts). A Titanium grade IV specimen $(\times 250)$; B titanium grade IV $(\times 2000)$; machined surface (Sa: $0.76 \mu \mathrm{m})$; $\mathbf{C}$ coated titanium specimen $(\times 250)$; $\mathbf{D}$ coated tita-

nium $(\times 2000)$; ultra-rough surface $($ Sa: $1.35 \mu \mathrm{m})$; $\mathbf{E}$ coated zirconia specimen $(\times 250)$; $\mathbf{F}$ coated zirconia $(\times 2000)$; medium rough surface (Sa: $0.43 \mu \mathrm{m})$; $\mathbf{G}$ milled zirconia specimen $(\times 250)$; $\mathbf{H}$ milled zirconia $(\times 2000)$; medium rough surface $(\mathrm{Sa}: 0.49 \mu \mathrm{m})$

Fig. 3 Cold atmospheric plasma (CAP) device experimental setting. A Energy control center with main unit, dental converter, patient probe, plasma device (Plasma ONE DENTAL); B glass instrument dental probe PS12 with transparent air chamber; $\mathbf{C}$ CAP application with ionization of atoms and molecules generating cold plasma. Zirconia specimens on sample holder; D EDS sample holder with titanium surface specimen (Phenom proX Scanning Electron Microscope)

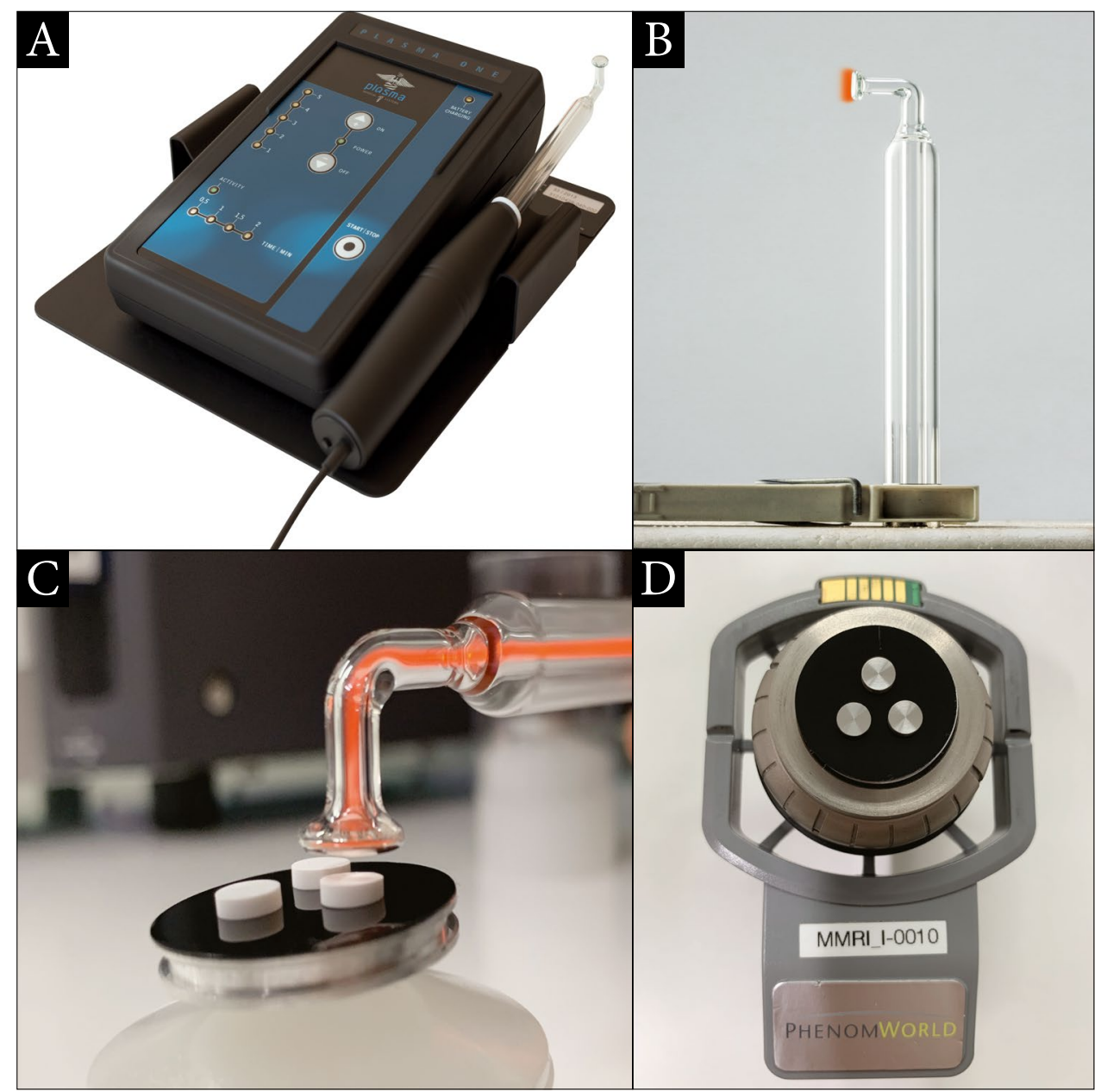


surfaces (CT). A group without any treatment served as a control. Cell adhesion took place for $24 \mathrm{~h}$ and $48 \mathrm{~h}$ post CAP treatment using a concentration of $\left(10^{4}\right.$ cells $\left./ 100 \mu \mathrm{l}\right)$. After the incubation process, all specimens were rinsed properly with phosphate-buffered saline (PBS) and further processed for scanning electron microscopy. A quantitative analysis was conducted. Cell counting was performed with the aid of the ImageJ software.

\section{Scanning electron microscopy}

To investigate morphological changes of CAP treatment on different implant surfaces, scanning electron microscopy was performed. Furthermore, specific patterns of cell adherence were evaluated for different cell types. After cell incubation with different CAP treatment modalities (ST/CT), a fixation process was conducted and specimens were sputter coated with a thin layer of titanium in a sputter coating unit (Scancoat Six, HHV, Crawley, United Kingdom). Examinations took place by scanning electron microscopy (Philips XL-30 ESEM). High-resolution images with a magnification of up to $2000 \times$ were obtained for in-depth analysis of cell behavior on different surfaces. Microscopic images were taken with magnifications of $50 \times$ choosing a random area of interest to allow for further quantitative analysis (Fig. 2). The study was performed in triplicate for each cell line after 1 or 2 days of incubation on zirconia discs. Due to a sparse contrast of cells incubated on coated titanium surfaces, applying scanning electron microscopy was not effective for quantitative analysis. Additional experiments were performed using fluorescence microscopy for these specimens.

\section{Energy-dispersive X-ray microanalysis (EDS)}

EDS was performed to analyze possible shifts in the elemental composition of different oral implant materials treated with CAP. The scientific workstation (Phenom proX Scanning Electron Microscope, Eindhoven, Netherlands) is equipped with a high-sensitivity backscattered electron (BSE) detector. The detector for the EDS and elemental analysis was a thermoelectrically cooled silicon drift detector (SDD) type, with a take-off angle (TOA) measuring $29^{\circ}$ an active detector area of $25 \mathrm{~mm}^{2}$. Titanium and zirconia discs were mounted on the sample holder with carbon tabs without touching the sample surface and analyzed with a scanning electron microscope in a particle-free clean room environment (according to Class 100 US Federal Standard 209E, Class 5 DIN EN ISO 14644-1) to avoid artifacts from the ambient air. The BSE detector allows for magnification of up to $100.000 \times$ with a resolution down to $15 \mathrm{~nm}$. Within this study, material-contrast images from $500 \times$ to a magnification of $10.000 \times$ were obtained.
To analyze the exact chemical composition of each sample, the acceleration voltage and atomic number of the element most characteristic of the substance's properties were adapted to investigate the outer layer $(3 \mu \mathrm{m})$ of the sample's surfaces. Calibration was done using a reference measurement by mapping $\mathrm{Cu} / \mathrm{Al}(8.040 \mathrm{keV} / 1.486 \mathrm{keV})$. The working distance was $3 \mathrm{~mm}$ with the field of view (FOV) at $53.8 \mu \mathrm{m}$ using a magnification of $5.000 \times$. Composition of the samples was assumed to be homogeneous. Microscopic analysis at three different detection points for each sample was done and EDS point analysis could be conducted. A reliable identification of elemental composition could be assumed with deconvolution measurements for X-ray quanta exceeding a minimum threshold (peak fit $\geq 0.99$ ). The proportion of atomic concentration and weighted concentration of the elements before and after CAP treatment were measured and footprints of the treated area were statistically calculated. Analysis of the spectra and processing of the data was conducted using software (Phenom Element Identification 3.8.4.0; ThermoFisher Scientific, Eindhoven, Netherlands). Monte-Carlo simulation is used for calculating the profiles of the target surface topography, illustrating the interaction between X-ray signals and volume of the samples. Simulation was set up with an acceleration voltage of $15 \mathrm{keV}$ using 10,000 electrons. Coated samples were calculated for layer thickness according to manufactures specification with $20 \mu \mathrm{m}$. All experiments, as well as the complete setup, as described above were performed at the Medical Materials Research Institute, Berlin, Germany. The laboratory is accredited according to DIN EN ISO/IEC 17,025 (Fig. 4).

\section{Analysis of gene expression}

Twenty-four hours after CAP application, total RNA was extracted using an RNA extraction (RNeasy) kit (Qiagen, Hilden, Germany). NanoDrop ND-2000 spectrophotometer (Thermo Fisher Scientific, Wilmington, DE, USA) was used to measure the RNA concentration. A total of $1 \mu \mathrm{g}$ of RNA was reverse transcribed into cDNA by use of iScript ${ }^{\mathrm{TM}}$ Select cDNA Synthesis Kit (Bio-Rad Laboratories, Munich, Germany) at $42{ }^{\circ} \mathrm{C}$ for $90 \mathrm{~min}$ followed by $85^{\circ} \mathrm{C}$ for $5 \mathrm{~min}$. One microliter of cDNA was amplified as a template in a $25 \mu$ reaction mixture containing $12.5 \mu 1$ SsoAdvanced ${ }^{\mathrm{TM}}$ Universal SYBR ${ }^{\circledR}$ Green Supermix (Bio-Rad), $2.5 \mu$ l of specific primers $(0.5 \mu \mathrm{M}$ each; predesigned QuantiTect Primer Assay, Qiagen), and $9 \mu 1$ deionized water. The mixture was at first heated at $95^{\circ} \mathrm{C}$ for $5 \mathrm{~min}$, and then followed by 40 cycles with denaturation at $95{ }^{\circ} \mathrm{C}$ for $10 \mathrm{~s}$ and combined annealing/extension at $60{ }^{\circ} \mathrm{C}$ for $30 \mathrm{~s}$. mRNA expression of Ki67, Proliferation-Cell-Nuclear-Antigen (PCNA), and Collagen-Typ1 alpha (COL1A1) was detected by real-time PCR using the iCycler iQ ${ }^{\mathrm{TM}}$ detection system (Bio-Rad). 
A
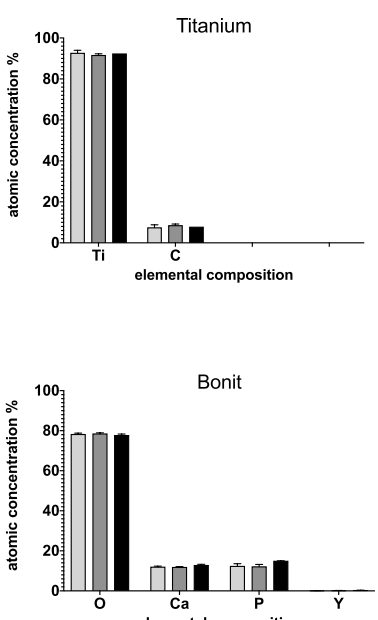
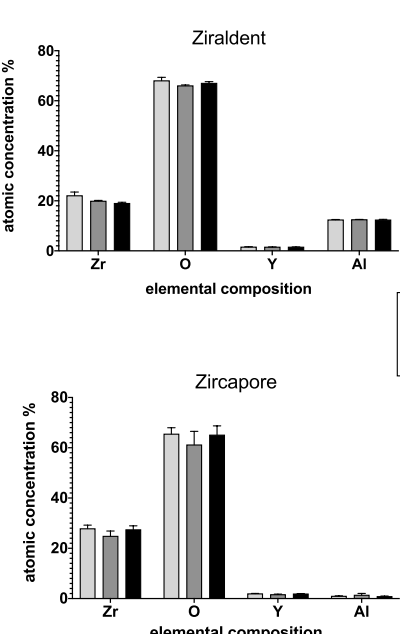

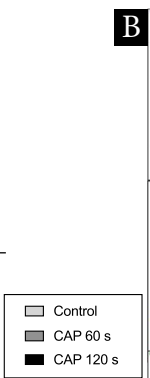

B

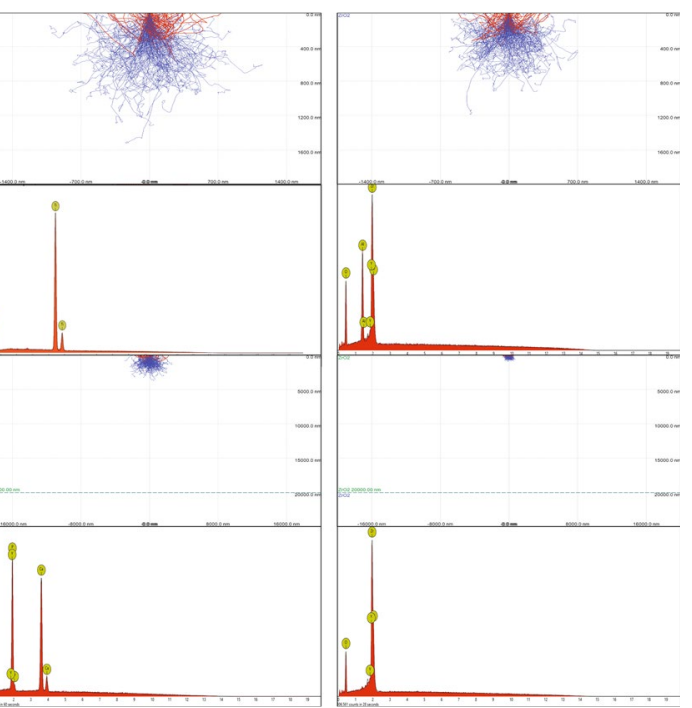

Ti: titanium; C: carbon; O: oxygen; Ca: calcium; P: phosphate; Y: yttrium; Zr: zirconium; Al: aluminium.

Fig. 4 EDS elemental analysis using Phenom Element Identification software 3.8.4.0. A Quantitative EDS analysis for CAP application identifying shifts of the atomic concentration for implant materials. Influences on the elemental composition using application times of 60 s/120 s. B Monte-Carlo simulation for EDS spectra and electron

Glyceraldehyde 3-phosphate dehydrogenase (GAPDH) was used as an endogenous control. The data was analyzed by the comparative threshold cycle method.

\section{Analysis of cell proliferation}

XTT (Cell Signaling Technology, Danvers, USA) kit was used to determine the cell viability on 96 -well plates. CAPtreated groups $(60 \mathrm{~s} / 120 \mathrm{~s})$, as well as untreated control of each cell type, were seeded on coated and non-coated titanium discs and incubated for $24 \mathrm{~h}$. Next, XTT reaction solution was added to each group according to the manufacturer's instructions. Measured specific absorbance (SA) was determined after $4 \mathrm{~h}$ of incubation with a microplate reader (Epoch $^{\mathrm{TM}}$ Microplate Spectrophotometer, BioTek Instruments, Winooski, USA). Optical density (OD) was determined at $450 \mathrm{~nm}$ (reference wavelength $690 \mathrm{~nm}$ ). For quantifications, the background levels of media without cultured cells were subtracted. Additionally, cell numbers of each group were determined by using an EVETM (NanoEnTek Inc., Seoul, Korea) automatic cell counter $24 \mathrm{~h}$ after both CAP application periods ( $60 \mathrm{~h} / 120 \mathrm{~s})$ of MG-63 cells as compared to untreated control.

\section{Fluorescence microscopy}

For visualization and quantitative analysis of titanium samples, we performed fluorescence staining of the cells at different time points. Cell suspensions of each cell type were prepared and stimulated as described above on both profiles of different implant surfaces/blue dotted line indicating the coating layer of titanium (Bonit $\left.{ }^{\circledR}\right)$ and superficial layer of zirconia (Zircapore $\left.{ }^{\circledR}\right)$ specimens. All the statistical significance values were declared as $p<0.05$

non-coated or pre-coated titanium samples for $24 \mathrm{~h}$ and $48 \mathrm{~h}$. Cell adhesion was analyzed with a Phalloidin/DAPI staining after fixation with $4 \%$ paraformaldehyde (Merck, Darmstadt, Germany) for 10 min and permeabilization with 0.05\% Triton X-100 (Merck) for 5 min in PBS. One hundred micromolar phalloidin (Merck) was used for $40 \mathrm{~min}$ in order to label the actin filaments. After washing, $1 \mu \mathrm{g} / \mathrm{ml}$ DAPI (Merck) was applied for 3 min to label DNA. Stained cells were embedded with Mowiol (SigmaAldrich) and evaluated with the ZOETM Fluorescent Cell Imager (Bio-Rad). The study was performed in triplicates and repeated two times for each cell. Six different areas of interest (AOI) were randomly assigned for calculation. In total, $72 \mathrm{AOI}$ were analyzed for cell attachment and pooled probes were quantitatively analyzed. For further quantitative measuring, nucleus staining was allowed for cell counting.

\section{Statistical analysis}

The design of the study with the sample size for each experiment is displayed (Fig. 1). For statistics, the GraphPad Prism9 Software (GraphPad Software, San Diego, USA) was used. All experiments were performed in triplicate and reproduced at least twice. For statistical comparisons between groups, the Kruskal Wallis test followed by the post hoc Dunnett's tests with corrected $p$-values were used for multiple comparisons. Differences between groups were considered significant at $p<0.05$. All data are presented as mean with standard error of the mean (SEM). EDS data were 
analyzed using two-way ANOVA followed by the post hoc Tukey's multiple comparison test using corrected $p$-values.

\section{Results}

\section{EDS analysis for surface elemental composition}

To investigate the influence of CAP on different implant materials and surface modifications regarding their topographical and physiochemical properties, EDS was performed. We speculated that exposure time could possibly have led to a shift in elemental composition on the atomic level. The EDS survey analysis of pure titanium implant surfaces revealed a large amount of titanium $92.5 \% \pm 2.41$ and a fraction of carbon $7.4 \% \pm 2.41$. Application of CAP showed no significant alterations in percentage composition irrespective of the exposure time (120 s). Calcium phosphate coated titanium specimens (BONIT®) showed to have a large amount of oxygen $78.1 \% \pm 1.48$ and a minor proportion of calcium $11.9 \% \pm 1.06$ and phosphate $9.8 \% \pm 0.34$. Only traces of yttrium could be detected (Table 1). EDS was not able to detect any signals of titanium within coated specimens since the coating layer of $20 \mu \mathrm{m}$ was not penetrated by X-ray signals, which only reached a detection depth of $5 \mu \mathrm{m}$ demonstrated through Monte-Carlo simulation (Fig. 4B). Zirconia specimens (Ziraldent ${ }^{\circledR}$ ) comprise a large amount of oxygen $68.1 \% \pm 2.98$ and approximately one-quarter of zirconia $21.4 \% \pm 3.59$ with a minor proportion of aluminum $12.3 \% \pm 0.32$ as well as small amounts of yttrium $1.5 \% \pm 0.17$. This chemical composition could not be altered by CAP treatment irrespective of the exposure time. High-resolution spectrum analysis confirmed comparable levels of oxygen, zirconia, and yttrium in those specimens (Zircapore $\left.{ }^{\circledR}\right)$. Although some shifts in carbon composition in the coated zirconia group could be observed, the standard deviation in the test objects was high and no significant results could be drawn regarding the influence of CAP.
Aluminum was significantly reduced in comparison with non-coated specimens $0.99 \% \pm 0.20$. Although the penetration depth using EDS was not able to reach the underlying surface of coated zirconia specimens, as shown for coated titanium objects using Monte-Carlo simulation, the main fractions remain stable for the basic elemental composition with no significant changes caused by CAP treatment.

\section{XTT analysis for cell proliferation}

Changes in cell proliferation of osteoblast-like cells (MG63), as well as human gingival fibroblast (HGF-1), were investigated using different application periods of CAP. Using an XTT assay, a significant increase in cell proliferation for MG-63 cells after $60 \mathrm{~s}$ of CAP treatment could be revealed $(p<0.05)$. Furthermore, an application time of $120 \mathrm{~s}$ caused a 1.6-fold increase of cell proliferation (Fig. 5A). When analyzing gingival fibroblasts, a constant increase in cell proliferation could be observed in both treated CAP groups. The application time of $120 \mathrm{~s}$ led to a 1.4-fold increase compared to the control yielding significant results (Fig. 5B).

\section{Adhesion assay}

The influences of CAP treatment on the adherence capability for oral cells regarding different dental implant materials were evaluated. In-depth analyses with high magnifications using scanning electron microscopy could demonstrate sufficient cell attachment on the implant materials investigated. Different patterns of adhesion between zirconia specimens coated (Zircapore $\left.{ }^{\circledR}\right)$ and non-coated (Ziraldent $\left.{ }^{\circledR}\right)$ were investigated. Fluorescence microscopy was used to detect cell adhesion on coated (Bonit $\left.{ }^{\circledR}\right)$ and non-coated (titanium grade IV) titanium specimens. Staining of cell nuclei with DAPI allowed for high-contrast display of MG-63 cells and HGF-1 even on coated titanium surfaces with a high background noise (Fig. 6).

Table 1 EDS elemental analysis for both untreated and plasma treatment (+CAP) surfaces (mean SEM)

\begin{tabular}{|c|c|c|c|c|c|c|c|c|}
\hline surface material & $\mathrm{Ti}$ [mass\%] & $\mathrm{C}$ [mass\%] & $\mathrm{O}$ [mass\%] & $\mathrm{Ca}$ [mass\%] & $\mathrm{P}$ [mass\%] & $\mathrm{Y}$ [mass\%] & $\mathrm{Zr}$ [mass\%] & $\mathrm{Al}$ [mass\%] \\
\hline Titanium & $92.5 \pm 1.39$ & $7.4 \pm 1.39$ & - & - & - & - & - & - \\
\hline Titanium + CAP & $91.5 \pm 0.72$ & $8.4 \pm 0.72$ & - & - & - & - & - & - \\
\hline Bonit & - & - & $78.1 \pm 0.60$ & $11.9 \pm 0.43$ & $9.8 \pm 0.14$ & $* *$ & - & - \\
\hline Bonit + CAP & - & - & $78.4 \pm 0.44$ & $11.7 \pm 0.33$ & $9.6 \pm 0.13$ & $* *$ & - & - \\
\hline Ziraldent & - & - & $68.1 \pm 1.12$ & - & - & $1.5 \pm 0.06$ & $21.4 \pm 1.36$ & $12.3 \pm 0.14$ \\
\hline Ziraldent + CAP & - & - & $67.4 \pm 0.85$ & - & - & $1.5 \pm 0.03$ & $20.7 \pm 0.80$ & $11.5 \pm 1.06$ \\
\hline Zircapore & - & n.s & $65.4 \pm 2.48$ & - & - & $1.9 \pm 0.09$ & $27.8 \pm 1.37$ & $0.99 \pm 0.09$ \\
\hline Zircapore + CAP & - & n.s & $61.1 \pm 5.35$ & - & - & $1.6 \pm 0.15$ & $24.8 \pm 2.05$ & $1.3 \pm 0.66$ \\
\hline
\end{tabular}

Tr titanium; C: carbon: O: oxygen; Ca: calcium: P: phosphate: Y: yttrium: Zr: zirconium: AI: aluminium. **Only trace amounts were present; n.s: data not significant 
Fig. 5 Determination of cell proliferation by XTT assay applying CAP at various durations. A Proliferation of MG-63 cells after CAP application with 60 s/120 s (intensity: $18 \mathrm{kV}$ ); B proliferation of HGF-1 cells after CAP application with $60 / 120 \mathrm{~s}$ (plasma device intensity: $18 \mathrm{kV}$ ); columns and error bars represent the mean and SEM of measured specific absorbance (SA)/(OD blanked 450-690 nm). Mean \pm SEM $(n=6)$; *significant $(p<0.05)$; $* * * *$ significant $(p<0.0001)$ difference between groups
A

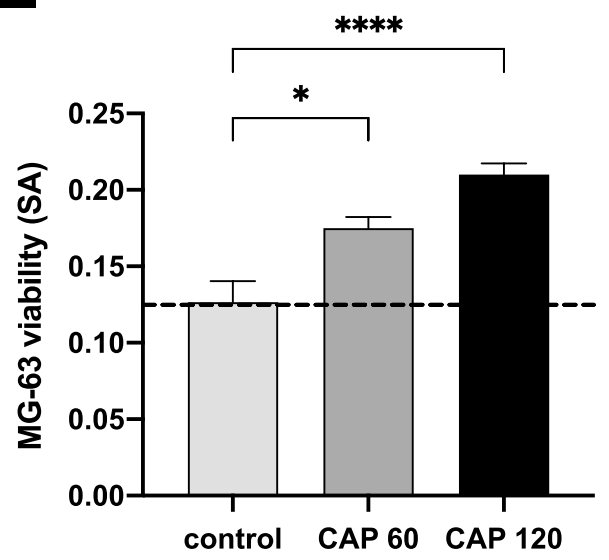

B

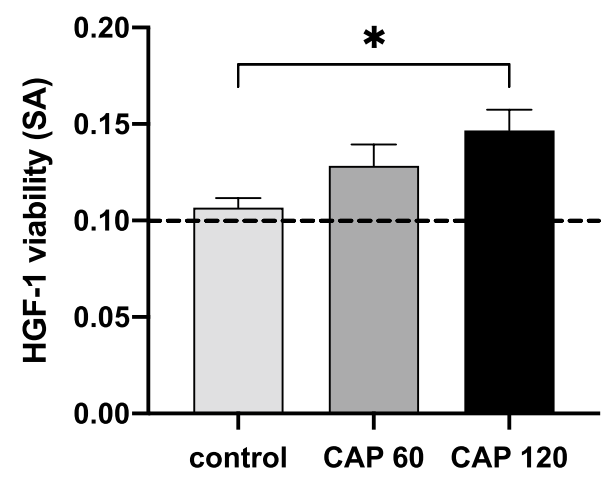

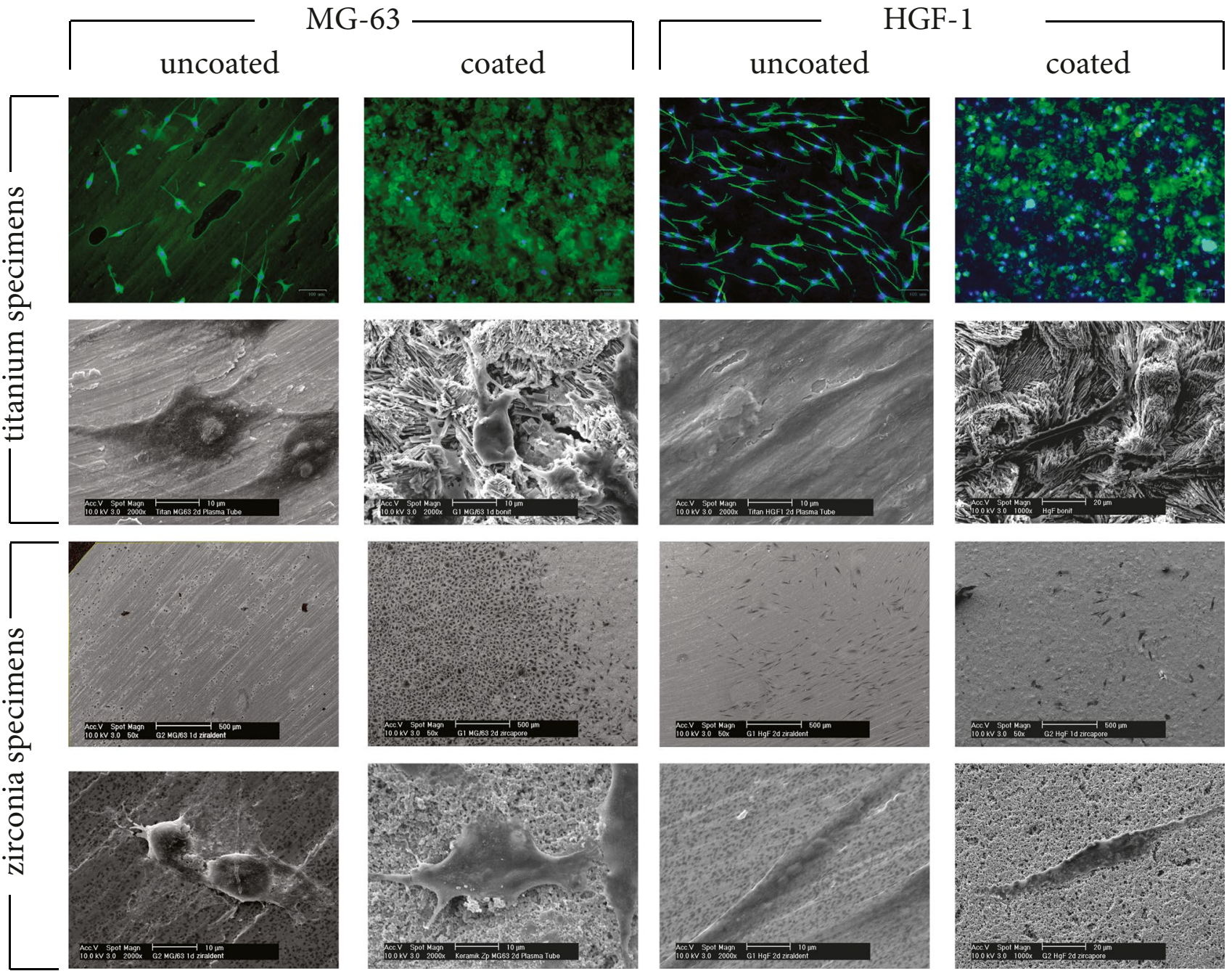

Fig. 6 Scanning electron microscopy/fluorescence microscopy detecting adhesion assay on titanium/zirconia specimens. Different cell types (MG-63) and (HGF-1) (columns); coated/uncoated implant surface materials (rows). Detailed images showing cell adhesion of cells using high magnification $(\times 2000)$. Fluorescence microscopy revealing staining of cell nuclei with DAPI (blue) and the cytoskeleton using phalloidin staining (green) 
Within an observation period of $24 \mathrm{~h}, \mathrm{MG}-63$ cell adhesion on titanium grade IV implant surfaces that had received stimulation with CAP prior to cell seeding (ST) was not altered. CAP stimulation of the cell suspension prior to seeding (CT) did not result in advanced cell adhesion. CAP treatment of coated titanium surfaces with a calcium-phosphate layer (Bonit ${ }^{\circ}$ ) resulted in 1.3-fold increase of cell adhesion for MG-63 cells after an observation period of $24 \mathrm{~h}$ (ST). In contrast, the pretreatment of cell suspension prior to seeding showed no significant effects (CT). After $48 \mathrm{~h}$ of incubation, a 2.8-fold increase on cell adhesion could be observed for MG-63 cells with pretreatment of the cell suspension whereas the surface treatment with CAP resulted in minor increases of 1.3-fold compared to the control. Similar observations could be confirmed with coated surfaces (Fig. 7A).

HGF-1 adhesion on titanium grade IV was reduced after surface stimulation (ST) or treatment of the cell suspension (CT) by 0.5 -fold within $2 \mathrm{~h}$. If using longer observation periods of up to $48 \mathrm{~h}$, no significant influences of CAP treatment regarding HGF-1 adhesion on titanium grade IV could be observed compared to the control. Same was evident regarding cell adhesion of HGF-1 on CAP-treated titanium specimens with coating (ST) after $24 \mathrm{~h}$ with a slight downregulation in (CT). Interestingly, given an observation period of $48 \mathrm{~h}$, a significant 1.9-fold increase in cell adhesion for HGF-1 was observed (Fig. 7B). The evaluation of cell adhesion on zirconia resulted in divergent patterns compared to titanium specimens. Uncoated zirconia surfaces (Ziraldent ${ }^{\circledR}$ ) showed less cell adhesion of MG-63 cells when pretreated (ST) with CAP after 24 h/48 h (0.5/0.4-fold). An increase of up to 1.9-fold of cell adhesion was measured after $24 \mathrm{~h}$ with cell treatment (CT) although data showed a high variation of responses. Coated specimens revealed no changes after $24 \mathrm{~h}$ and a slight increase after $48 \mathrm{~h} \mathrm{com-}$ pared to the control receiving surface treatment (ST). In contrast, cell treatment with CAP (CT) showed a decrease in adhesion of MG-63 cells (Fig. 7C). Constant decrease in cell adhesion was observed for HGF-1 compared to the control on zirconia specimens in both coated and uncoated surfaces within $24 \mathrm{~h}$ independent from the treatment method. Coated specimens (Zircapore ${ }^{\circledR}$ ) revealed a decrease of cell adhesion (0.6/1.7-fold). Comparable patterns of decreased cell adhesion for HGF-1 were observed within $48 \mathrm{~h}$ for uncoated specimens except for surface treatment (ST) where an upregulation (1.2-fold) was observed. For coated specimens (Zircapore $\AA$ ), a slight increase compared to the control (0.6/0.7-fold) after $48 \mathrm{~h}$ was evident. The variance (SEM) was high in this experiment. Adjusted $p$-values $>0.99$ show no significance (Fig. 7D).

\section{Influence of CAP on MG-63 gene expression}

When analyzing gene expression of MG-63 cells on uncoated titanium grade IV specimens, a significant increase of mRNA expression for Ki67, COL1A $(p<0.005)$, and IL-6 $(p<0.0001)$ was evident for CAP stimulation of the cell suspension prior to seeding (ST). PCNA was increased within both groups (ST, CT) although data were not significant (Fig. 8A). Analyzing the mRNA expression on coated titanium specimens (Bonit $\AA$ ), a significant upregulation
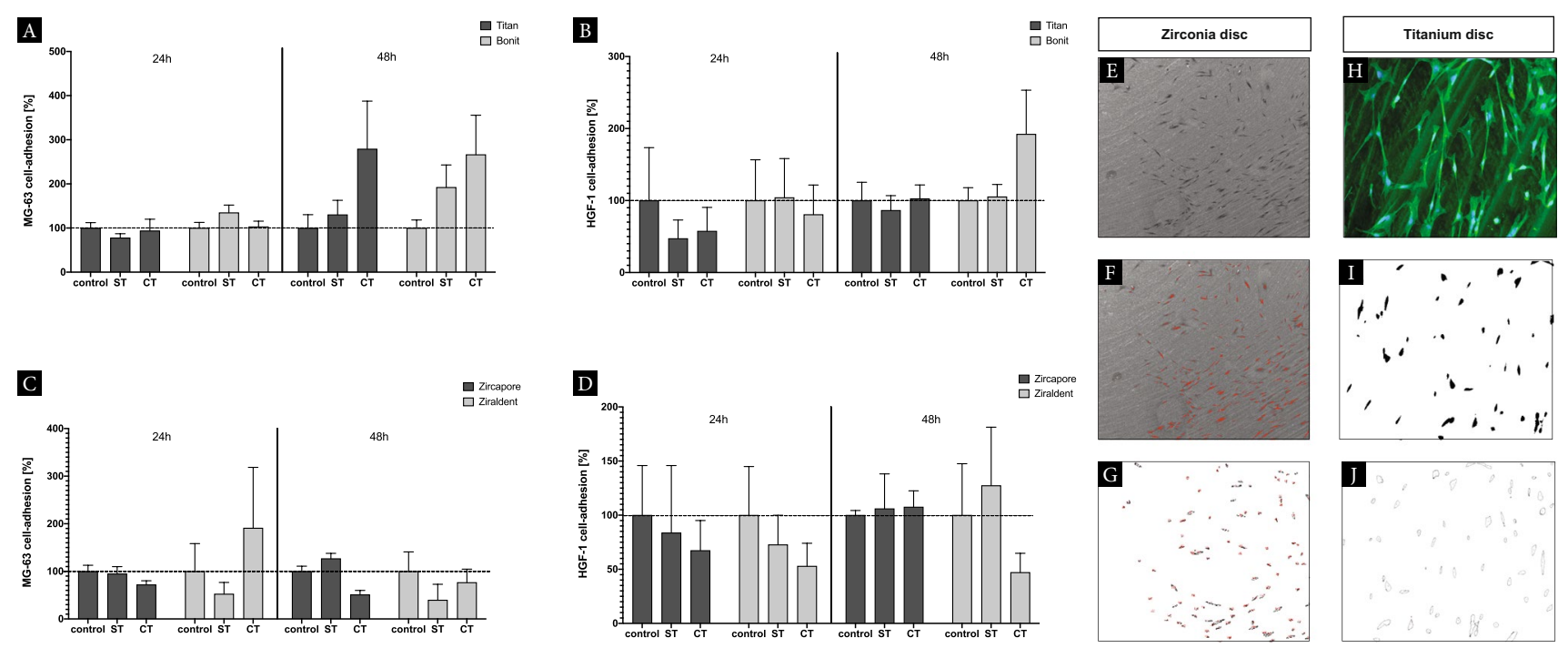

Fig. 7 CAP adhesion assay. A-D Adjusted percentage of cell adhesion after $(24 \mathrm{~h} / 48 \mathrm{~h})$ of different CAP treatment modalities. Untreated specimens/cells served as control, surface treatment (ST), cell treatment (CT); columns and error bars represent the mean $\pm \operatorname{SEM}(n=3)$. E/H Cell quantification using ImageJ Software, microscopic detection of cell colony within the area of interest (AI) $(\times 50)$. F/I Image transformation for cell detection using 8-bit resolution (Process: Binary: Make Binary) with cell separation G/J automatic cell counting (Menu: Analyse Particles) narrowing particle size (Size: 25-Infinity/Circularity: 0.00-1.00) 


\section{A}
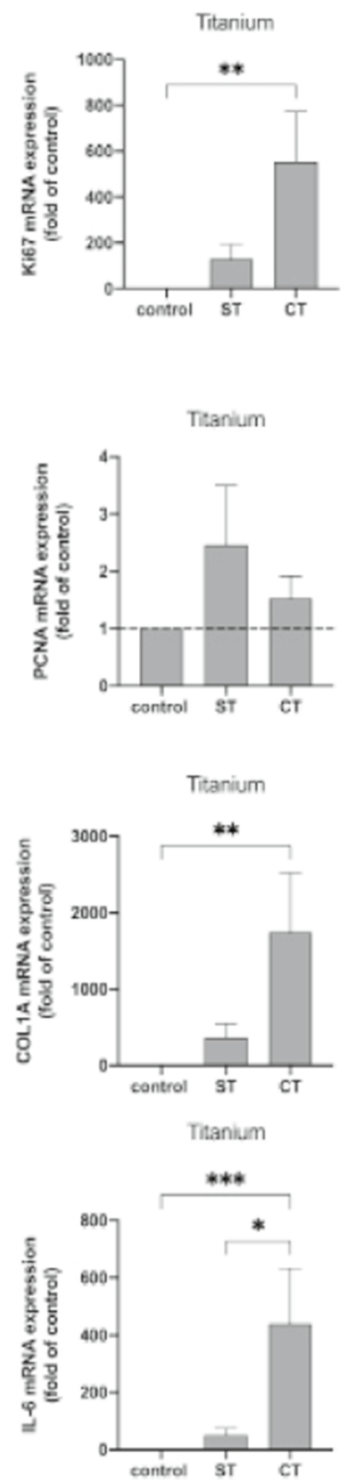

B
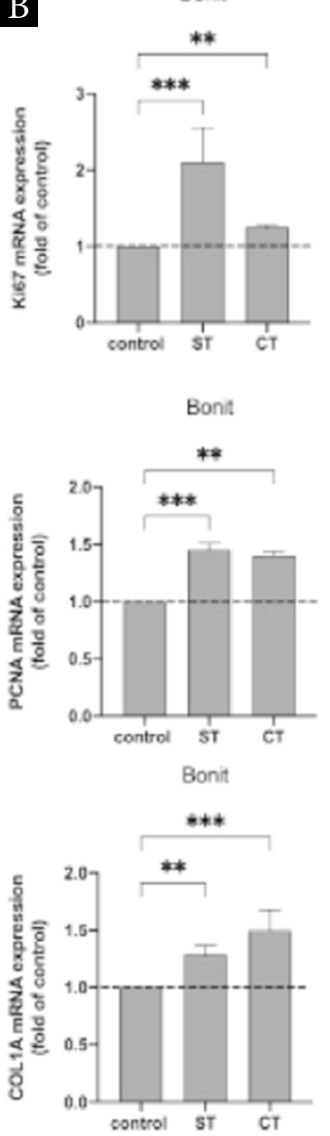

Bonit

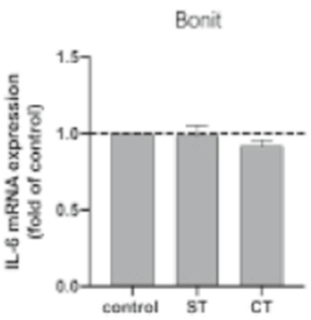

C
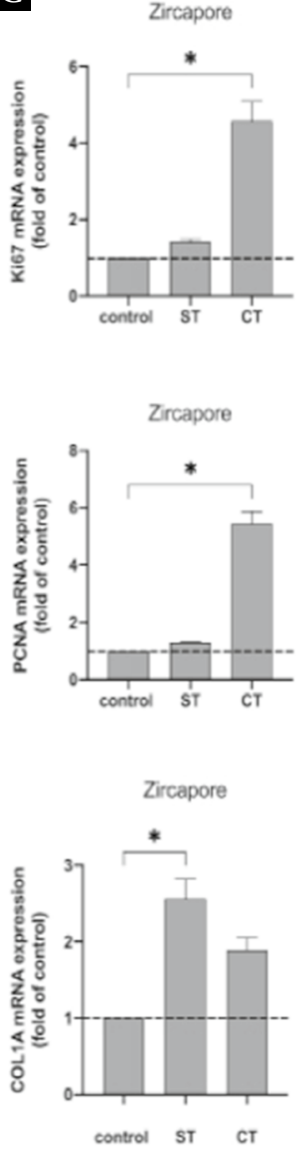

Zircapore

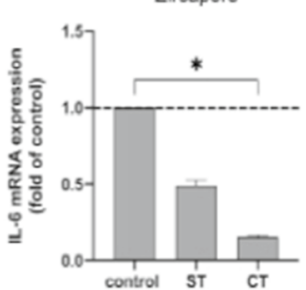

D
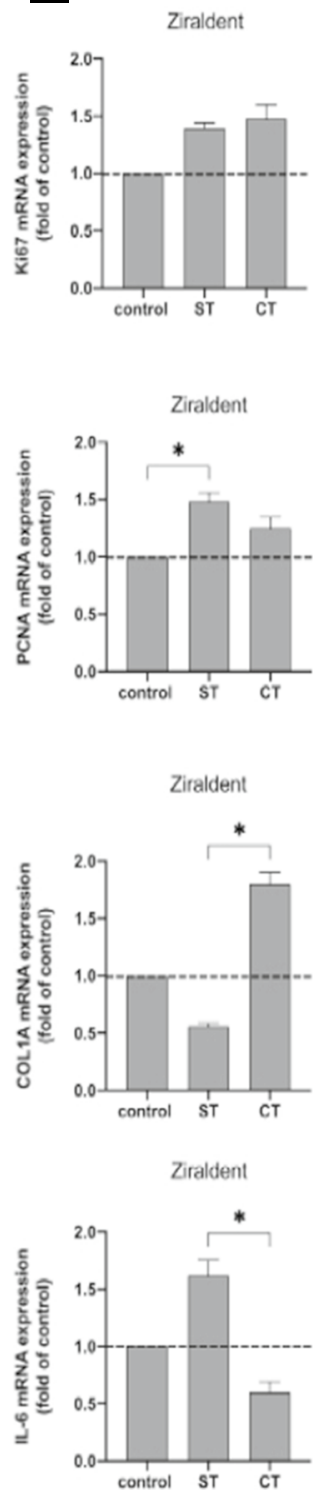

Fig. 8 CAP influence on mRNA expression of osteoblast-like cells (MG-63) using different implant surfaces. A Uncoated titanium specimen. B Coated titanium specimen (Bonit $\left.{ }^{\circ}\right)$, untreated specimens/ cells served as control, surface treatment (ST), cell treatment (CT). C Coated ceramic specimen (Zircapore ${ }^{\circledR}$ ) untreated specimens/cells

was observed for implant surfaces that received stimulation with CAP prior to cell seeding (ST). Ki67 and PCNA were upregulated $(p<0.0001)$ as well as COL1A $(p<0.005)$. Additionally, a significant increase in mRNA expression was examined for treatment of cell suspension (CT) for these genes. The mRNA expression of IL- 6 thus was not changed significantly (Fig. 8B). Analysis of coated zirconia specimens (Zircapore ${ }^{\circledR}$ ) revealed upregulation of mRNA expression for Ki67 and PCNA comparing CT with the control $(p<0.05)$. COL1A was upregulated significantly after served as control, surface treatment (ST), cell treatment (CT) (plasma device intensity: $18 \mathrm{kV}$ ). D Uncoated ceramic specimen (Ziraldent ${ }^{\circledR}$ ) (plasma device intensity: $18 \mathrm{kV}$ ); columns and error bars represent the mean \pm SEM $(n=9)$; statistical difference between groups: $* p<0.05 ; * * p<0.005 ; * * * p<0.0001$

CAP stimulation of the surfaces (ST) whereas values for IL-6 were decreased and showed significant downregulation compared to the control $(p<0.05)$ (Fig. 8C). Uncoated zirconia specimens revealed an upregulation for Ki67 (not significant). PCNA was increased when comparing ST with the control $(p<0.05)$. A difference between surface treatment (ST) favoring cell suspension treatment (CT) was evident for COL1A $(p<0.05)$. The mRNA expression for IL-6 was upregulated when CAP treatment of the surface was performed (ST). In contrast, treatment of the cell suspension 
(CT) led to a significant downregulation compared to ST. Compared to the control, the expression of IL- 6 was reduced (Fig. 8D).

\section{Discussion}

The antimicrobial capacity of CAP using ambient air could be proven in past studies with varying efficacy regarding different bacterial species. Additionally, CAP was shown to be effective in eradicating biofilm activity on implant materials [27-30]. Strategies investigating the potential role of adjunctive treatment using argon cold plasma device during biofilm removal on titanium surfaces demonstrated enhanced regrowth of osteoblast cells. Whereas a combination of an optimized air polishing and argon plasma application could not prove enhanced osteoblast spreading on rough implant surfaces [31, 32]. Moreover, preclinical animal studies with a focus on argon plasma treatment revealed enhanced boneto-implant contact (BIC) after functionalization of implant surfaces [33]. A recent meta-analysis came to conclusion that plasma treatment using argon may present an effective method for improving osseointegration [34]. Other investigations have also demonstrated enhanced osseointegration through ambient air-generated CAP for titanium surfaces and calcium-phosphate-coated implants [35]. The surface elemental chemistry was modified by this treatment resulting in a higher degree of exposure for adsorbed carbon species immediately after plasma treatment [36]. Interestingly, other studies investigating the influence of CAP on implant osseointegration revealed higher levels of carbon within their specimens $(45.0 \% \pm 5.1)$ compared to our observations and a decrease when plasma treatment was performed $(38.0 \% \pm 4.7)$. The fraction of titanium was significantly lower in this study using Ti-6Al-4 V bulk alloy implants. Increased levels of titanium $(19.0 \% \pm 3.9)$ and oxygen $(43.0 \% \pm 4.3)$ could be observed when plasma treatment was performed. Calcium-phosphate-coated implants showed lower values of oxygen $(42.0 \% \pm 5.2)$ compared to our data but comparable values for calcium and phosphate. The authors showed an increase of those values after CAP treatment [37]. Recently, the elemental composition and purity of dental implant surfaces of commercial zirconia implants have been investigated using non-destructive energy-dispersive X-ray spectroscopy (EDS) revealing comparable results to our investigation. The amount of aluminum within the specimens was similar to rough areas used for sampling of commercially available dental zirconia implants [38]. Monte-Carlo simulation was able to demonstrate that EDS analysis failed to detect the surface below the outside layer of titanium and zirconia specimens to analyze changes of the underlying elemental composition. It can be speculated that CAP, which leads to the ionization of atoms and molecules, also does not penetrate the surface layer within $20 \mu \mathrm{m}$. However, manipulation of the elemental chemistry of dental implants by plasma treatment could possibly lead to legislative implications affecting the European medical device regulation [MDR] effective from May 2021. Our data revealed no alterations in the basic elemental composition. Neither for titanium specimens nor for zirconia surfaces irrespective of different application times. CAP has shown to alter the surface energy and chemical topography due to the generation of high concentration of reactive species increasing the wettability and initial cellular interaction [39]. Additionally, plasma treatment can facilitate early osseointegration of any biocompatible implant surface regardless of its chemistry and topography change [40]. For a complete elemental and isotopic analysis of the implant body with high sensitivity and low detection limits down to the ultra-trace level $(<0.0001$ mass \%, equivalent to $<1 \mathrm{ppm})$, inductively coupled plasma mass spectrometry (ICP-MS) and inductively coupled plasma optical emission spectrometry (ICPOES) are currently the methods of choice [41]. We could demonstrate that CAP treatment increases proliferation and viability of MG-63 cells and HGF-1 on titanium surfaces. Using application times of 60 to $120 \mathrm{~s}$ suggests that CAP could be beneficial to promote wound healing around dental implants as described earlier [26, 42]. Additionally, other cell types such as fibroblasts and epithelial cells, as well as keratinocytes, have been described to show higher levels of cell migration under the influence of cold plasma treatment [43-45]. Further in vitro and in vivo studies need to clarify the specific cellular context. Direct or indirect influences of CAP treatment must be differentiated since we could reveal different cellular patterns dependent on the application method. Adhesion assays were performed since the phases of cell-biomaterial interactions are crucial and destine to produce growth and differentiation factors to further establish innate biophysical properties of the implant surfaces [46]. Surface topography determines the cellular attachment of oral cells [47]. A variety of studies have explored the impact of roughness leading to improved techniques to refine surface conditions of abutments and fixtures [48-50]. Smooth titanium surfaces favor fibroblast attachment whereas rougher blasted surfaces promote osteoblast proliferation. Apical migration of junctional epithelium can be expected compared to grooved surfaces implicating that a certain threshold roughness $(\mathrm{Ra}=0.22 \mu \mathrm{m})$ promotes a stable soft tissue seal. Initial attachment and spreading of human gingival fibroblasts are influenced by the surface texture of ceramic abutments [50]. We could not compare cell adhesion of MG-63 cells HGF-1 based on the surface layer because sizes of the specimens differed given the industrial manufacturing process. Thus, the number of cells that were used for the adhesion experiment was not equal in all experiments. Nevertheless, according to other studies, we 
could confirm that soft tissue sealing by fibroblast adhesion could be positively influenced by non-thermal plasma treatment $[51,52]$. Likewise, the adhesion of MG-63 cells is positively influenced by CAP treatment on titanium surfaces given the opportunity of enhancing the osseointegration capacity. This early biological response of gingival cells needs to be reevaluated since we cannot outline possible detrimental influences by the saturation effect leading to rapid cell growth on the small zirconia discs. Furthermore, the effects of CAP on zirconia surfaces are not unambiguous and should be investigated using larger sample sizes and equal dimensions of the specimens. CAP treatment of MG-63 cells revealed different patterns of gene regulation affecting markers responsible for tissue remodeling of the extracelllular matrix (ECM). A significant upregulation of Ki67 and PCNA is observed when sample surfaces of cell suspensions are treated. This process of active cell proliferation due to CAP treatment could be confirmed [24]. The ossification process is promoted by osteoblasts through gene expression of COL1A $[53,54]$. Treatment of cell suspensions with CAP leads to upregulation on all investigated implant surfaces implying promotion of osseointegration. Proinflammatory genes like IL- 6 are regulated differently with irregular patterns of regulation comparing different titanium and zirconia specimens. Evaluation of mRNA levels was conducted 7 days after CAP application since the surface area of the specimens yielded only small quantities of RNA within 2 days of seeding. Thus, data of mRNA levels represent long-term effects of CAP treatment. Hence, it became obvious that CAP effects on gene expression are time dependent. Recent studies on the effect of CAP on apoptosis in MG-63 cells imply that CAP might help to enhance the healing of chronical hard tissue wound [24]. It remains unclear if CAP could be a useful tool in the treatment of mucositis or periimplantitis. Further studies would have to aim on observations focusing on the nano-level not only on the micron-level of implant surfaces to reveal possible shifts in terms of surface energy, wettability, and initial bone-implant contact in a time-dependent manner comparing ambient and argon plasma treatment alone or in conjunction.

\section{Conclusion}

Regarding possible implications for CAP on medical implants we conclude that adjunctive treatment of titanium and zirconia surfaces could possibly enhance the healing capacity in difficult clinical situations with poor bone quality and quantity. Coating of implant surfaces may alter the effects of CAP on gene expression influencing the ECM. This therapeutic strategy could ultimately promote the osseointegration process of dental implants even for patients where bone metabolism is reduced.

\section{Limitations}

The main limitation of this study is a small sample size increasing the margin of error. The adhesion assay using different implant materials could have gained more statistical power using specimens with equal dimensions in a larger quantity. Nevertheless, a trend could be observed on the effects of CAP treatment providing a scientific basis for an adequate sample size calculation to support further studies. It should also be noted that MG-63 osteoblast-like cells were used for the study. While these cells are commonly used as hard tissue cells, human osteoblasts better represent the hard tissue situation around implants [46, 48]. However, we focused on these cells because of their easier handling. Further studies on human osteoblasts from the jawbone are necessary before clinical application. To reveal clinical implications for soft tissue integration of dental implants treated with CAP, the use of periodontal ligament cells can be considered. Additionally, it should be kept in mind that for CAP treatment, a specific concentration cannot be defined, as would be possible with drug treatments. The only thing the dentist can adjust in CAP application is the treatment time, leading to timedependent effects [49]. In the present study, we focused ourselves on a CAP treatment of $60 \mathrm{~s}$ and $120 \mathrm{~s}$. It should also be kept in mind that implants have a cylindrical surface, which is only comparable to platelets to a limited extent. A treatment of this surface would therefore take significantly longer. Further treatment times and other surface conformations should therefore be the focus of future studies using standardized techniques. In the present study, we focused on analysis of mRNA expression of Ki67, PCNA, COL1a1, and IL6. Due to the number of other analyses, we have limited ourselves to these crucial markers for proliferation, extracellular matrix, and inflammation. The influence of CAP on mRNA expression of different cells, such as TGF $\beta$, VEGF, IL8, APAF1, or CASP3, has been described in the literature [50, 51, 55]. Further studies should clarify how these and markers such as other cytokines and chemokines, matrix metalloproteinases, or apoptotic factors in cells on implant surfaces are influenced by CAP. As various other strategies for peri-implant therapy are also known, e.g., the application of $\mathrm{CHX}$, the use of antibiotics, or the application of lasers or photodynamic therapy, a combination of CAP with one or more of these methods may present possible synergistic effects.

Acknowledgements Our sincere thanks go to FairImplant $\mathrm{GmbH}$ (Bönningstedt, Germany), DOT GmbH (Rostock, Germany), and 
MetoxitAG (Thayngen, Switzerland) who kindly provided various specimens. The authors would also like to thank Ms. Ramona Menden and Ms. Anna Weber, Ms. Jana Marciniak, and Mr. Lehnard Seher as well as Mr. Stefan Schwarzmüller and Mr. Carsten Pape for their technical valuable support.

Author contribution G.W. and M.N. conceived the ideas and are responsible for the conception and design of the study. Acquisition of data and interpretation as well as writing of the manuscript were conducted as leading researchers. B.E. and M.N. collected and analyzed data and added ideas and substantial input to the study design as well as to the manuscript. D.D. and C.B. provided materials and equipment for data analysis and gave intellectual content.

Funding Open Access funding enabled and organized by Projekt DEAL. The work was supported by the University Hospital Bonn, Germany.

All authors gave final approval of the version to be published and provided critical revision ensuring that questions related to the accuracy or integrity of the work were appropriately investigated and resolved.

\section{Declarations}

Ethics approval This article does not contain any studies with human participants or animals performed by any of the authors. All applicable international, national, and/or institutional guidelines for the care and use of animals were followed.

Informed consent For this type of study, formal consent is not required.

Conflict of interest The authors declare no competing interests.

Open Access This article is licensed under a Creative Commons Attribution 4.0 International License, which permits use, sharing, adaptation, distribution and reproduction in any medium or format, as long as you give appropriate credit to the original author(s) and the source, provide a link to the Creative Commons licence, and indicate if changes were made. The images or other third party material in this article are included in the article's Creative Commons licence, unless indicated otherwise in a credit line to the material. If material is not included in the article's Creative Commons licence and your intended use is not permitted by statutory regulation or exceeds the permitted use, you will need to obtain permission directly from the copyright holder. To view a copy of this licence, visit http://creativecommons.org/licenses/by/4.0/.

\section{References}

1. Masuda T, Salvi GE, Offenbacher S, Felton DA, Cooper LF (1997) Cell and matrix reactions at titanium implants in surgically prepared rat tibiae. Int J Oral Maxillofac Implants 12:472-485

2. Brunski JB (1999) In vivo bone response to biomechanical loading at the bone/dental-implant interface. Adv Dent Res 13:99-119. https://doi.org/10.1177/08959374990130012301

3. Grassi S, Piattelli A, de Figueiredo LC, Feres M, de Melo L, Iezzi G, Alba RC Jr, Shibli JA (2006) Histologic evaluation of early human bone response to different implant surfaces. J Periodontol 77:1736-1743. https://doi.org/10.1902/jop.2006.050325

4. Albrektsson T, Wennerberg A (2004) Oral implant surfaces: Part 1 -review focusing on topographic and chemical properties of different surfaces and in vivo responses to them. Int J Prosthodont 17:536-543

5. Smeets R, Stadlinger B, Schwarz F, Beck-Broichsitter B, Jung O, Precht C, Kloss F, Grobe A, Heiland M, Ebker T (2016) Impact of dental implant surface modifications on osseointegration. Biomed Res Int 2016:6285620. https://doi.org/10.1155/2016/6285620

6. Wennerberg A, Albrektsson T, Chrcanovic B (2018) Long-term clinical outcome of implants with different surface modifications. Eur J Oral Implantol 11(Suppl 1):S123-S136

7. AlKahtani RN (2018) The implications and applications of nanotechnology in dentistry: a review. Saudi Dent J 30:107-116. https://doi.org/10.1016/j.sdentj.2018.01.002

8. Xuereb M, Camilleri J, Attard NJ (2015) Systematic review of current dental implant coating materials and novel coating techniques. Int J Prosthodont 28:51-9. https://doi.org/10.11607/ijp. 4124

9. Sul YT, Byon ES, Jeong Y (2004) Biomechanical measurements of calcium-incorporated oxidized implants in rabbit bone: effect of calcium surface chemistry of a novel implant. Clin Implant Dent Relat Res 6:101-110. https://doi.org/10.1111/j.1708-8208.2004. tb00032.x

10. Ribeiro AR, Gemini-Piperni S, Travassos R, Lemgruber L, Silva RC, Rossi AL, Farina M, Anselme K, Shokuhfar T, ShahbazianYassar R (2016) Trojan-like internalization of anatase titanium dioxide nanoparticles by human osteoblast cells. Sci Rep 6:23615. https://doi.org/10.1038/srep23615

11. Saldana L, Vilaboa N (2010) Effects of micrometric titanium particles on osteoblast attachment and cytoskeleton architecture. Acta Biomater 6:1649-1660. https://doi.org/10.1016/j.actbio.2009.10. 033

12. Jung S, Bohner L, Hanisch M, Kleinheinz J, Sielker S (2018) Influence of implant material and surface on differentiation and proliferation of human adipose-derived stromal cells. Int J Mol Sci 19. https://doi.org/10.3390/ijms19124033

13. Darveau RP, Curtis MA Oral biofilms revisited: a novel host tissue of bacteriological origin. Periodontol 2000 86:8-13

14. Kotsakis GA (2000) Olmedo DG (2021): Peri-implantitis is not periodontitis: scientific discoveries shed light on microbiomebiomaterial interactions that may determine disease phenotype. Periodontol 86:231-240

15. Ichioka Y, Kado T, Mashima I, Nakazawa F, Endo K, Furuichi Y (2019) Effects of chemical treatment as an adjunctive of airabrasive debridement on restoring the surface chemical properties and cytocompatibility of experimentally contaminated titanium surfaces. J Biomed Mater Res B Appl Biomater. https://doi.org/ 10.1002/jbm.b.34377

16. Persson LG, Ericsson I, Berglundh T, Lindhe J (2001) Osseintegration following treatment of peri-implantitis and replacement of implant components. An experimental study in the dog. J Clin Periodontol 28:258-263. https://doi.org/10.1034/j.1600-051x. 2001.028003258.x

17. Yilmaz S, Algan S, Gursoy H, Noyan U, Kuru BE, Kadir T (2013) Evaluation of the clinical and antimicrobial effects of the Er:YAG laser or topical gaseous ozone as adjuncts to initial periodontal therapy. Photomed Laser Surg 31:293-298. https://doi.org/10. 1089/pho.2012.3379

18. Guo L, Zou Z, Smeets R, Kluwe L, Hartjen P, Cacaci C, Gosau M, Henningsen A (2020) Time dependency of non-thermal oxygen plasma and ultraviolet irradiation on cellular attachment and mRNA expression of growth factors in osteoblasts on titanium and zirconia surfaces. Int J Mol Sci 21. https://doi.org/10.3390/ijms2 1228598

19. Han A, Tsoi JKH, Matinlinna JP, Zhang Y, Chen Z (2018) Effects of different sterilization methods on surface characteristics and biofilm formation on zirconia in vitro. Dent Mater 34:272-281. https://doi.org/10.1016/j.dental.2017.11.012 
20. Pham CM, Chen CY, Kim DM (2021) The effects of using erbium, chromium-doped:yttrium-scandium-gallium-garnet laser on the surface modification, bacterial decontamination, and cell adhesion on zirconia discs: an in vitro study. Lasers Med Sci. https://doi. org/10.1007/s 10103-021-03313-1

21. Hui WL, Perrotti V, Iaculli F, Piattelli A, Quaranta A (2020) The emerging role of cold atmospheric plasma in implantology: a review of the literature. Nanomaterials (Basel) 10

22. Theinkom F, Singer L, Cieplik F, Cantzler S, Weilemann H, Cantzler M, Hiller KA, Maisch T, Zimmermann JL (2019) Antibacterial efficacy of cold atmospheric plasma against Enterococcus faecalis planktonic cultures and biofilms in vitro. PLoS ONE 14:e0223925. https://doi.org/10.1371/journal.pone.0223925

23. Komasa S, Kusumoto T, Hayashi R, Takao S, Li M, Yan S, Zeng Y, Yang Y, Hu H, Kobayashi Y (2021) Effect of argon-based atmospheric pressure plasma treatment on hard tissue formation on titanium surface. Int J Mol Sci 22

24. Eggers B, Marciniak J, Deschner J, Stope MB, Mustea A, Kramer FJ, Nokhbehsaim M (2021a) Cold atmospheric plasma promotes regeneration-associated cell functions of murine cementoblasts in vitro. Int J Mol Sci 22

25. Eggers B, Marciniak J, Memmert S, Kramer FJ, Deschner J, Nokhbehsaim M (2020) The beneficial effect of cold atmospheric plasma on parameters of molecules and cell function involved in wound healing in human osteoblast-like cells in vitro. Odontology. https://doi.org/10.1007/s10266-020-00487-y

26. Kleineidam B, Nokhbehsaim M, Deschner J, Wahl G (2019) Effect of cold plasma on periodontal wound healing-an in vitro study. Clin Oral Investig 23:1941-1950. https://doi.org/10.1007/ s00784-018-2643-3

27. Hafner S, Ehrenfeld M, Neumann AC, Wieser A (2018) Comparison of the bactericidal effect of cold atmospheric pressure plasma (CAPP), antimicrobial photodynamic therapy (aPDT), and polihexanide (PHX) in a novel wet surface model to mimic oral cavity application. J Craniomaxillofac Surg. https://doi.org/10. 1016/j.jcms.2018.09.006

28. Idlibi AN, Al-Marrawi F, Hannig M, Lehmann A, Rueppell A, Schindler A, Jentsch H, Rupf S (2013) Destruction of oral biofilms formed in situ on machined titanium (Ti) surfaces by cold atmospheric plasma. Biofouling 29:369-379. https://doi.org/10. 1080/08927014.2013.775255

29. Koban I, Holtfreter B, Hübner NO, Matthes R, Sietmann R, Kindel E, Weltmann KD, Welk A, Kramer A, Kocher T (2011) Antimicrobial efficacy of non-thermal plasma in comparison to chlorhexidine against dental biofilms on titanium discs in vitro - proof of principle experiment. J Clin Periodontol 38:956-965. https://doi.org/10.1111/j.1600-051X.2011.01740.x

30. Ulu M, Pekbagriyanik T, Ibis F, Enhos S, Ercan UK (2018) Antibiofilm efficacies of cold plasma and er: YAG laser on Staphylococcus aureus biofilm on titanium for nonsurgical treatment of peri-implantitis. Niger J Clin Pract 21:758-765. https://doi.org/ 10.4103/njcp.njcp_261_17

31. Duske K, Jablonowski L, Koban I, Matthes R, Holtfreter B, Sckell A, Nebe JB, von Woedtke T, Weltmann KD, Kocher T (2015) Cold atmospheric plasma in combination with mechanical treatment improves osteoblast growth on biofilm covered titanium discs. Biomaterials 52:327-334

32. Matthes R, Duske K, Kebede TG, Pink C, Schlüter R, von Woedtke T, Weltmann KD, Kocher T, Jablonowski L (2017) Osteoblast growth, after cleaning of biofilm-covered titanium discs with air-polishing and cold plasma. J Clin Periodontol 44:672-680

33. Canullo L, Tallarico M, Botticelli D, Alccayhuaman KAA, Martins Neto EC, Xavier SP (2018) Hard and soft tissue changes around implants activated using plasma of argon: a histomorphometric study in dog. Clin Oral Implants Res 29:389-395
34. Pesce P, Menini M, Santori G, Giovanni E, Bagnasco F, Canullo L (2020) Photo and plasma activation of dental implant titanium surfaces. A systematic review with meta-analysis of pre-clinical studies. J Clin Med 9

35. Coelho PG, Lemons JE (2009) Physico/chemical characterization and in vivo evaluation of nanothickness bioceramic depositions on alumina-blasted/acid-etched Ti-6Al-4V implant surfaces. J Biomed Mater Res A 90:351-361. https://doi.org/10.1002/jbm.a. 32097

36. Guastaldi FP, Yoo D, Marin C, Jimbo R, Tovar N, Zanetta-Barbosa D, Coelho PG (2013) Plasma treatment maintains surface energy of the implant surface and enhances osseointegration. Int J Biomater 2013:354125. https://doi.org/10.1155/2013/354125

37. Danna NR, Beutel BG, Tovar N, Witek L, Marin C, Bonfante EA, Granato R, Suzuki M, Coelho PG (2015) Assessment of atmospheric pressure plasma treatment for implant osseointegration. Biomed Res Int 2015:761718. https://doi.org/10.1155/2015/ 761718

38. Beger B, Goetz H, Morlock M, Schiegnitz E, Al-Nawas B (2018) In vitro surface characteristics and impurity analysis of five different commercially available dental zirconia implants. Int J Implant Dent 4:13. https://doi.org/10.1186/s40729-018-0124-8

39. Duske K, Koban I, Kindel E, Schroder K, Nebe B, Holtfreter B, Jablonowski L, Weltmann KD, Kocher T (2012) Atmospheric plasma enhances wettability and cell spreading on dental implant metals. J Clin Periodontol 39:400-407. https://doi.org/10.1111/j. 1600-051X.2012.01853.x

40. Berger MB, Bosh KB, Cohen DJ, Boyan BD, Schwartz Z (2021) Benchtop plasma treatment of titanium surfaces enhances cell response. Dent Mater 37:690-700. https://doi.org/10.1016/j.dental.2021.01.026

41. Mohr V, Miró M, Limbeck A (2017) On-line dynamic extraction system hyphenated to inductively coupled plasma optical emission spectrometry for automatic determination of oral bioaccessible trace metal fractions in airborne particulate matter. Anal Bioanal Chem 409:2747-2756. https://doi.org/10.1007/ s00216-017-0219-8

42. Eggers B, Marciniak J, Memmert S, Wagner G, Deschner J, Kramer FJ, Nokhbehsaim M (2021) Influences of cold atmospheric plasma on apoptosis related molecules in osteoblast-like cells in vitro. Head Face Med 17:37. https://doi.org/10.1186/ s13005-021-00287-x

43. Arndt S, Unger P, Wacker E, Shimizu T, Heinlin J, Li YF, Thomas HM, Morfill GE, Zimmermann JL, Bosserhoff AK (2013) Cold atmospheric plasma (CAP) changes gene expression of key molecules of the wound healing machinery and improves wound healing in vitro and in vivo. PLoS ONE 8:e79325. https://doi.org/10. 1371/journal.pone.0079325

44. Lendeckel D, Eymann C, Emicke P, Daeschlein G, Darm K, O'Neil S, Beule AG, von Woedtke T, Völker U, Weltmann KD (2015) Proteomic changes of tissue-tolerable plasma treated airway epithelial cells and their relation to wound healing. Biomed Res Int 2015:506059. https://doi.org/10.1155/2015/506059

45. Schmidt A, Bekeschus S, Wende K, Vollmar B, von Woedtke T (2017) A cold plasma jet accelerates wound healing in a murine model of full-thickness skin wounds. Exp Dermatol 26:156-162. https://doi.org/10.1111/exd.13156

46. Ventre M, Netti PA (2016) Engineering cell instructive materials to control cell fate and functions through material cues and surface patterning. ACS Appl Mater Interfaces 8:14896-14908. https:// doi.org/10.1021/acsami.5b08658

47. Rohr N, Bergemann C, Nebe JB, Fischer J (2020) Crystal structure of zirconia affects osteoblast behavior. Dent Mater 36(7):905-913. https://doi.org/10.1016/j.dental.2020.04.017

48. Bosshardt DD, Chappuis V, Buser D (2017) Osseointegration of titanium, titanium alloy and zirconia dental implants: current 
knowledge and open questions. Periodontol 2000 73:22-40. https://doi.org/10.1111/prd.12179

49. Jemat A, Ghazali MJ, Razali M, Otsuka Y (2015) Surface modifications and their effects on titanium dental implants. Biomed Res Int 2015:791725. https://doi.org/10.1155/2015/791725

50. Mustafa K, Odén A, Wennerberg A, Hultenby K, Arvidson K (2005) The influence of surface topography of ceramic abutments on the attachment and proliferation of human oral fibroblasts. Biomaterials 26:373-378. https://doi.org/10.1016/j.biomateria 1s.2004.02.037

51. Canullo L, Genova T, Gross Trujillo E, Pradies G, Petrillo S, Muzzi M, Carossa S, Mussano F (2020) Fibroblast interaction with different abutment surfaces: in vitro study. Int J Mol Sci 21. https://doi.org/10.3390/ijms21061919

52. Kwon JS, Kim YH, Choi EH, Kim CK, Kim KN, Kim KM (2016 Se) Non-thermal atmospheric pressure plasma increased mRNA expression of growth factors in human gingival fibroblasts. Clin Oral Investig 20(7):1801-1808. https://doi.org/10.1007/ s00784-015-1668-0
53. Clarke B (2008) Normal bone anatomy and physiology. Clin J Am Soc Nephrol 3(Suppl 3):S131-S139. https://doi.org/10.2215/cjn. 04151206

54. Kusumbe AP, Ramasamy SK, Adams RH (2014) Coupling of angiogenesis and osteogenesis by a specific vessel subtype in bone. Nature 507:323-328. https://doi.org/10.1038/nature13145

55. Hotta E, Hara H, Kamiya T, Adachi T (2018) Non-thermal atmospheric pressure plasma-induced IL-8 expression is regulated via intracellular $\mathrm{K}+$ loss and subsequent ERK activation in human keratinocyte HaCaT cells. Arch Biochem Biophys 15(644):64-71. https://doi.org/10.1016/j.abb.2018.03.005

Publisher's note Springer Nature remains neutral with regard to jurisdictional claims in published maps and institutional affiliations. 